\title{
PROGRAM PERLINGDUNGAN KESEHATAN DI TEMPAT KERJA MANAJEMEN RISIKO PENYAKIT PARU AKIBAT KERJA
}

\author{
Icha dameyanti br sebayang
}

Email : $\underline{\text { ichasebayang19@gmail.com }}$

\section{Latar Belakang}

Masalah Keselamatan dan Kesehatan Kerja (K3) secara umum di Indonesia masih sering ter-abaikan. Hal ini ditunjukkan dengan masih tingginya angka kecelakaan kerja. Pada tahun 2014, terdapat 40.694 kasus Penyakit Akibat Kerja (PAK) di Indonesia. Sebanyak 418 kasus terjadi di Kalimantan Selatan.1Penyakit Akibat Kerja (PAK) dan Kecelakaan Kerja (KK) di kalangan masyarakat di Indonesia belum tercatat dengan baik.

Jika dilihat angka kecelakaan dan penyakit akibat kerja di beberapa negara maju (dari beberapa pengamatan) menunjukkan kecenderungan peningkatan prevalensi. Sebagai faktor penyebab, sering terjadi karena kurangnya kesadaran pekerja dan kualitas serta keterampilan pekerja yang kurang memadai.Banyak pekerja yang meremehkan risiko kerja,sehingga tidak menggunakan alat-alat pengaman walaupun sudah tersedia. Penjelasan Undang-Undang Nomor 23 Tahun 1992 tentang Kesehatan telah mengamanatkan antara lain, setiap tempat kerja harus melaksanakan upaya kesehatan kerja,agar tidak terjadi gangguan kesehatan pada peker-ja, keluarga, masyarakat dan lingkungan diseki-tarnya.2Penyakit akibat kerja disebabkan oleh dua faktor, yaitu lingkungan kerja dan hubungan kerja.

Penyakit akibat kerja atau berhubungan dengan pekerjaan dapat disebabkan oleh pemajanan di lingkungan kerja.3 Industri pengelasan merupakan tempat kerja dengan aktivitas yang berisiko tinggi yang dapat menimbulkan gangguan kesehatan dan kelelahan kerja yang berdampak pada kecelakaan kerja. Di Indonesia, bengkel las mudah dijumpai di pinggir jalan 4Beberapa bengkel las berada pada jalan raya yang ramai dilewati oleh masyarakat umum seperti yang terdapat di sepanjang jalan A. Yani Kota Banjarbaru yang merupakan jalur utama antar provinsi di Kalimantan Selatan.

Aktivitas jalan raya dapat menimbulkan kebisingan lalu lintas di jalan raya yang tinggi yang dapat menimbulkan ketidaknyamanan yang mengganggu konsentrasi kerja sehingga pekerja dapat mengalami kelelahan dan menyebabkan penyakit akibat kerja.Hasil penelitian Zulfina menyebutkan bahwa sebanyak $63 \%$ pekerja las mengalami kelelahan kerja berat sehingga dapat berakibat pada kejadian kecelakaan kerja dan penyakit akibat kerja 5Penelitian ini bertujuan mengetahui faktor penyebab penyakit akibat kerja pada pekerja las di sepanjang jalan A. Yani Kota Banjarbaru. Pentingnya penggunaan APD dalam bekerja di bagian las diperlukan oleh pekerja dan bagi pemilik industri yang merupakan kewajiban yang tidak 
terpisahkan. Begitu juga dengan faktor usia, masa kerja, lama kerja, peningkatan pengetahuan juga merupakan bagian penting untuk mencegah terjadinya penyakit akibat kerja.

\section{Metode}

Desain studi yang digunakan adalah cross-sectional dengan pendekatan Analisis Risiko Kesehatan Lingkungan (ARKL). Analisis Risiko adalah proses yang bertujuan untuk menghitung atau memperkirakan risiko pada suatu organisme sasaran, sistem atau populasi, termasuk identifikasi ketidak pastian yang menyertainya, setelah terpajan oleh agent tertentu, dengan memperhatikan karakteristik yang melekat pada agent yang menjadi perhatian dan karakteristik sistem sasaran yang spesifik. ARKL digunakan dalam penelitian ini untuk menghitung tingkat risiko kesehatan dan melakukan prediksi tingkat risiko kesehatan menurut proyeksi waktu pajanan jangka panjang akibat BTX.Penelitian dilaksanakan pada periode bulan Maret-Juni 2014. Pengumpulan data dilakukan melalui wawancara untuk mendapatkan data antropometri pada petugas gerbang tol dan pengukuran konsentrasi BTX di udara di gerbang tol Kebun Jeruk, Jakarta.

Sebagai kontrol pembanding, dilakukan wawancara pada pekerja administrasi yang bekerja di dalam ruang kantor dan pengukuran konsentrasi BTX pada kantor administrasi. 20 resresponden pada kelompok pekerja pintu tol terpajan BTX dan 15 responden pada kelompok pembanding yaitu total karyawan yang ada di bagian administrasi merupakan sampel responden.

Jumlah sampel BTX udara diambil dari dua titik lokasi untuk masing-masing lokasi pintu tol dan kantor administrasi dengan masing-masing titik diukur sebanyak 3 kali pengukuran.Pengukuran konsentrasi BTX udara dengan menggunakan metode pengukuran NIOSH 1501 (NIOSH, 2003) dengan bahan pipa pengabsosbsi karbon aktif (charcoal) yaitu dengan menggunaksan tehnik Gas Chromatography (GC). Besar risiko BTX (RQ) dihitung melalui data konsentrasi BTX, jumlah asupan (I) dan nilai RfC dan CSF, seperti diuraikan pada Perhitungan diakukan dengan pemodelan karakterisasi risiko berdasarkan model Louvar \& Louvar (1998), dengan cara menghitung tingkat risiko yang dinyatakan dengan Risk Quotient.

\section{Hasil}

Jenis penelitian ini adalah observasional sedangkan pendekatan yang digunakan dalam penelitian ini adalah pendekatan cross sectional. Pada penelitian ini yang digunakan sebagai populasi adalah seluruh petugas pintu tol (operasional) dari pintu tol Tangerang hingga pintu tol Karawaci yang berjumlah 84 orang. Pengambilan sampel dalam penelitian ini dilakukan secara tidak acak (nonprobability sampling) dengan teknik sampling purposive, yaitu teknik pengambilan sampel berdasarkan pertimbangan tertentu antara lain:1. Mengikuti lengkap pemeriksaan pemeriksaan Medical Check Up (MCU)2. Tidak mempunyai riwayat penyakit paru3. Bersedia menjadi sampel penelitianVariabel dalam penelitian ini dibagi menjadi 2, yaitu 
variabel dependen yang terdiri dari gangguan fungsi paru, serta variabel independen yang terdiri dari umur, kebiasaan merokok, kebiasaan olahraga, status gizi, jenis kelamin, masa kerja serta penggunaan APD(masker).4. HasilHasil survey yang telah terkumpul kemudian dilakukan pengolahan data dengan melalui tahapan antara lain; 1.Memberikan nomor dan kode pada setiap lembar kuisioner yang diperoleh. 2.Melakukan pengecekan termasuk kelengkapan dan kejelasan isi pada kuisioner.3.

Gangguan fungsi paru dilihat berdasarkan hasil MCU PT. Jasa Marga 2014, yang dikelompokan menjadi restriksi ringan, restriksi sedang, restriksi berat.4. Menghitung skor IMT dilakukan perbandingan berat badan dalam kg dan tinggi badan dalam $\mathrm{m} 2$ dan hasilnya dikelompokan menjadi gemuk dan kurus serta normal.a. Analisis UnivariatAnalisis Unvariat digunakan untuk menjelaskan atau mendeskripsikan distribusi frekuensi masing-masing variabel yang diteliti, gangguan fungsi paru, umur, kebiasaan merokok, kebiasaan olahraga, status gizi, jenis kelamin, masa kerja, dan penggunaan APD (masker).

Hasil distribusi sif kerja, masa kerja, budaya K3 dan fungsi paru pada pekerja tambang di PT X sinergi pada memaparkan hasil berdasarkan analisis univariat untuk mendapatkan distribusi fekuensi dari masing-masing variabel independen (sif kerja, masa kerja, dan budaya K3) dan variabel dependen (gangguan fungsi paru). Hasil penelitian menunjukkan kasus fungsi paru tidak normal sebesar 57,9\% meliputi obstruktif, restruktif maupun keduanya menunjukkan hubungan antarvariabel independen dengan variabel dependen. Seluruh variable meliputi sif dan masa kerja, serta budaya 3 memiliki hubungan yang bermakna secara statistik dengan nilai $\mathrm{p}<$ 0,05. Variabel bebas yang berhubungan dengan variabel terikat (variabel sif kerja, masa kerja, dan budaya K3) bersama dimasukkan dalam perhitungan uji regresi logistik metode Enter. Sif kerja merupakan variabel bebas yang berpengaruh paling dominan dengan fungsi paru

\section{Pembahasaan}

Hasil penelitian dengan menggunakan uji kai kuadrat menunjukkan terdapat hubungan antara sif kerja dan fungsi paru pekerja tambang batu bara dikarenakan nilai $\mathrm{p}<0,05$. Dalam penelitian ini, terdapat bahwa kapasitas fungsi paru pekerja tambang batu bara sif siang ada yang mengalami penurunan kapasitas fungsi paru di bawah nilai normal, yaitu FEV1 80\%. Hal ini sesuai dengan penelitian Hendryx and Melissa, 15 membuktikan bahwa risiko tinggi pekerja tambang batu bara terhadap terjadinya inflamasi yang menyebabkan risiko gangguan fungsi paru. Dibuktikan oleh penelitian Sari Mumuya,16 pada tahun 2006 terhadap 299 laki-laki pekerja tambang batu bara sif siang di Tanzania dengan nilai $\mathrm{p}=0,04$ (nilai $\mathrm{p}<0,05$ ) menunjukkan bahwa risiko bekerja di daerah pertambangan batu bara dapat menurunkan nilai FEV1\% 80. Berdasarkan data yang diperoleh, terdapat nilai kapasitas fungsi paru pekerja tambang batu bara sif malam mengalami penurunan dibandingkan sif siang. Penurunankapasitas fungsi paru lebih banyak ditemukan pada pekerja tambang batu bara sif malam. Sif malam menunjukkan penurunan FEV1\%, Vmax50, 
Vmax 25 lebih besar dibandingkan dengan sif pagi dan sif siang. Menurut Zheng,10 sif malam merupakan sistem yang berlawanan dengan ritme sirkadian. Kelainan pola tidur sebagai salah satu bentuk gangguan ritme sirkadian yang dialami pekerja sif memiliki konsekuensi patologis berupa peningkatan kadar sitokin proinflamasi dalam darah karena penurunan sistem kekebalan dan antioksidan dalam tubuh. Hal ini didukung oleh penelitian Sholihah membuktikan bahwa dinding alveoli tikus wistar yang dikondisikan sif malam mengalami penebalan lebih signifikan dibandingkan sif siang. Penurunan kapasitas fungsi paru dapat disebabkan kondisi fisik individu pekerja yang meliputi mekanisme pertahanan paru anatomi dan fisiologi saluran pernapasan serta factor imunologis 18 Dibuktikan oleh penelitian Siyoum,19 pada tahun 2014 di Etiopia dengan nilai $\mathrm{p}=0,001$ yang menjelaskan bahwa gejala gangguan fungsi paru terjadi lebih banyak pada pekerja sif malam dibandingkan dengan sif lainnya.Hasil penelitian dengan menggunakan uji kai kuadrat menunjukkan bahwa terdapat hubungan antara masa kerja dan fungsi paru pekerja tambang batu bara, dikarenakan nilai $p>0,05$. Penelitian ini tidak sejalan dengan penelitian Puspita dkk,20 mengenai pengaruh paparan debu batu bara terhadap gangguan faal paru. Hasil analisis faktor risikonya menunjukkan bahwa masa kerja tidak memiliki hubungan terhadap kejadian gangguan faal paru. Dalam penelitian Baharuddin dkk,21 masa kerja 2- 7 tahun dan 8 13 tahun juga tidak memiliki hubungan dengan gangguan fungsi paru, baru pada masa kerja 14 20 tahun mulai terdapat hubungan dengan gangguan fungsi paru. Beberapa penelitian melaporkan bahwa di negara yang telah memiliki nilai ambang batas debu, pneumokoniosis pada penambang batu bara biasanya terjadi pada individu yang telah bekerja selama $>10$ tahun atau paling sedikit 5 - 10 tahun. Hal ini menunjukkan bahwa terdapat bukti yang signifikan antara masa kerja dengan fungsi paru. Jika masa kerja berhubungan,diperlukan waktu paparan yang cukup lama untuk dapat menimbulkan kelainan pada faal paru. Jumlah total suatu zat yang diabsorsi di paru-paru bukan hanya tergantung pada lamanya seseorang terpapar dengan debu saja, namun perlu diperhitungkan sifat-sifat kimia dan fisik dari debu itu sendiri yang terhirup oleh pekera .22Penurunan fungsi paru tidak hanya disebabkan oleh faktor pekerjaan maupun lingkungan kerja, tetapi juga terdapat sejumlah faktor nonpekerjaan yang dapat menjadi faktor yang memengaruhi maupun menjadi variable pengganggu. Hal-hal yang dapat memengaruhi seperti usia, jenis kelamin, kelompok etnis, tinggi badan, kebiasaan merokok, suhu lingkungan, penggunaan alat pelindung diri, metode pengolahan serta jumlah jam kerja/jam giliran kerja (sif kerja). 23 Faktor lain dalam penelitian ini yang menyebabkan masa kerja menjadi tidak berhubungan dengan fungsi paru adalah kadar debu. Pada penelitian ini, kadar debu batu bara merupakan faktor pengganggu yang tidak dapat dikendalikan karena setiap hari semua pekerja tambang batu bara di bagian produksi berkontak langsung dengan debu batu bara.Hasil penelitian ini menunjukkan terdapat hubungan antara budaya K3 dan fungsi paru pekerja tambang batu bara dikarenakan nilai $\mathrm{p}>0,05$. Penelitian ini sesuai dengan penelitian terdahulu yang dilakukan oleh Duma dkk, 1 yang mendesain modul menuju selamat sehat sebagai metode dan media penyuluhan K3 yang efektif meningkatkan pengetahuan, sikap dan perilaku K3 (budaya K3) serta tenaga kerja inovatif dalam pengendalian 
gangguan kesehatan. Hasil penelitian menyatakan penyuluhan K3 dalam penerapannya selama satu tahun efektif meningkatkan pengetahuan dan sikap budaya K3, namun belum efektif meningkatkan kesehatan pekerja. Berdasarkan hasil observasi di PT X, Rantau, Kalimantan Selatan, nilai ambang batas debu tidak diketahui. Manajemen perusahaan tambang batu bara hanya menyatakan secara lisan bahwa nilai ambang batas debu dalam keadaan normal. 24 Kadar debu lebih dari $350 \mathrm{mg} / \mathrm{m} 3$ udara/hari $(\mathrm{OR}=2,8 ; 95 \% \mathrm{CI}=1,8$ - 9,9) merupakan salah satu faktor intrinsik yang terbukti berhubungan dengan penurunan kapasitas paru Berdasarkan kepustakaan, debu yang berukuran antara 5 - 10 mikron bila terhisap akan tertahan dan tertimbun pada saluran napas bagian atas, yang berukuran antara 3 - 5 mikron tertahan atau tertimbun pada saluran napas tengah. Partikel debu dengan ukuran 1 - 3 mikron disebut debu respirabelmerupakan yang paling berbahaya karena tertahan atau tertimbun mulai dari bronkiolus terminalis sampai alveoli

\section{Kesimpulan}

Hasil penelitian menunjukkan terdapat hubungan sif kerja, masa kerja, dan budaya K3 dengan fungsi paru pekerja tambang batu bara PT X di Kalimantan Selatan Berdasarkan hasil penelitian mengenai "Faktor faktor yang Berhubungan dengan Gangguan Fungsi Paru pada Petugas Operasional Penjaga Pintu Tol Tangerang-Karawaci PT. Jasa Marga Cabang Jakarta-Tangerang” dengan kesimpulan sebagai

berikut:

1. Berdasarkan hasil penelitian, karakteristik responden yang tertinggi berumur $<45$ tahun sebanyak 30 orang $(54,5 \%)$, dan jenis kelamin laki-laki sebanyak 35 orang $(63,3 \%)$.

2. Proporsi responden yang tidak bersiko (IMT normal) sebanyak 33 orang (60\%), proporsi respnden yang mengalami restriksi ringan sebanyak 36 orang $(65,5 \%)$, proporsi responden tidak merokok sebanyak 32 orang $(58,2 \%)$, proporsi responden yang tidak olahraga sebanyak 28 orang $(50,9 \%)$, proporsi responden masa kerja $<22$ tahun sebanyak 29 orang $(52,7 \%)$, dan proporsi responden yang tidak pakai masker sebanyak 31 orang $(56,4 \%)$.

3. Tidak ada hubungan umur dengan gangguan fungsi paru, nilai odds ratio 3,033, hal ini menunjukan bahwa umur $>45$ tahun mempunyai resiko terjadinya terjadinya gangguan fungsi paru sebesar 3 kali dibandingkan dengan umur $<45$ tahun.

4. Tidak ada hubungan jenis kelamin dengan gangguan fungsi paru, nilai odds ratio 2,000, hal ini menunjukan bahwa jenis kelamin laki laki mempunyai resiko terjadinya gangguan fungsi paru sebesar 2 kali dibandingkan perempuan. 
5. Tidak ada hubungan status gizi dengan gangguan fungsi paru, nilai odds ratio 1,143 , hal ini menunjukan bahwa pekerja yang status gizi beresiko (gemuk dan kurus) mempunyai resiko terjadinya gangguan fungsi paru 1,1 kali dibanding pekerja yang tidak beresiko (IMT normal).

6. Tidak ada hubungan penggunaan APD (masker) dengan gangguan fungsi paru, nilai odds ratio 1,100 , hal ini menunjukan bahwa pekerja yang tidak menggunakan masker saat bekerja mempunyai resiko terjadinya gangguan fungsi paru 1,1 kali dibanding pekerja yang menggunakan masker.

7. Ada hubungan kebiasaan merokok dengan gangguan fungsi paru, nilali odds ratio 5,633, hal ini menunjukan bahwa pekerja yang memiliki kebiasaan merokok mempunyai resiko terjadinya gangguan fungsi paru 5,6 kali dibanding yang tidak memiliki kebiasaan merokok.

8. Ada hubungan kebiasaan olahraga dengan gangguan fungsi paru, nilali odds ratio 4,400, hal ini menunjukan bahwa pekerja yang tidak memiliki kebiasaan olahraga mempunyai resiko terjadinya gangguan fungsi paru 4,4 kali dibanding pekerja yang memiliki kebiasaan olahraga. Ada hubungan masa kerja dengan gangguan fungsi paru, nilai odds ratio 3,833, hal ini menunjukan bahwa pekerja yang masa kerja $>22$ tahun mempunyai resiko terjadinya gangguan fungsi paru 3,8 kali dibanding pekerja yang masa kerjanya $<22$ tahun 


\section{Daftar Pustaka}

Baharudin S, Roestam AW, Yunus F, Ikhsan M, Kekalih A. Analisis hasilspirometri karyawan PT. X yang terpapar debu di area penambangandan pemrosesan nikel. Jakarta: Departemen Pilmonologi dan Ilmu kedokteran Respirasi Fakulta Kedokteran Universitas Indonesia; 2010.

Cahyana A. Faktor yang berhubungan dengan kejadian gangguan fungsi paru pada pekerja tambang batubara PT. Indominco Mandiri Kalimantan Timur Tahun 2012 [research article]. Makassar:BagianKesehatan dan Keselamatan Kerja FKM Universitas Hasanuddin, 2012.

Dewan Keselamatan dan Kesehatan Kerja Nasional. Rapat pleno DK3N 2007.Jakarta: Institusi; 2007.

Dewan Keselamatan dan Kesehatan Kerja Nasional. Rapat pleno DK3N 2007.Jakarta: Institusi; 2006.

Departemen Kesehatan RI. Pedoman pelayanan kesehatan kerja padaPuskesmas kawasan/sentra industri. Keputusan Menteri Kesehatan RI Nomor:038/MENKES/SK///2007. Jakarta: Direktorat Bina Kesehatan Kerja. 2007.

Duma K, Husodo AH, Soebijanto, Maurits LS. Modul menuju selamatsehat: inovasi penyuluhan kesehatan dan kesehatan kerja dalampengendalian kelelahan kerja. Jurnal Manajemen Pelayanan Kesehatan.2011; 14 (4): 213-23.

Hermanus MA. Occupational health and safety in mining-status, Newdevelopments, and concerns. The Journal of the Southern African Institute of Mining and Metalurgy. 2007; 107: $531-8$.

Hendryx M, Melissa M. Relations between health indicators and resi $\square$ dential proximity to coal mining in West Virginia. American Journal of Public Health. 2008; 98 (4): 668-71.

International Commission on Occupational Health. Basic occupational healthservices. ICOH; 2002

Levy BS, Wegman DH. Ocupational health, an overview. In: Levy BS, WegmanDH, editors. Occupational health. 4th ed. Philadelphia: Lippincott Williams \&Wilkins; 2000.ning in West Virginia. American Journal of Public Health. 2008; 98 (4): 668-71.

Simamora, R. H. (2020). Pelatihan Komunikasi Efektif untuk Meningkatkan Efikasi diri Perawat dalam Pelaksanaan Identifikasi Pasien. JURNAL ILMIAH KESEHATAN MASYARAKAT:

Media Komunikasi Komunitas Kesehatan Masyarakat, 12(1), 49-54.

Simamora, R. H. (2011). ROLE CONFLICT OF NURSE RELATIONSHIP WITH PERFORMANCE IN THE EMERGENCY UNIT OF HOSPITALS RSD DR. SOEBANDI JEMBER. The Malaysian Journal of Nursing, 3(2), 23-32. 